\title{
ЛюДВІГ ВІТГЕНШТЕЙН І БУДДИЗМ
}

\author{
Г.А. Балута
}

Нічого не приховано.

II. Bimzенитейн

Оцінка філософських підсумків сучасної доби буде неповною, якщо не брати до уваги філософську спадщину Л. Вітгенштейна. Величезна кількість публікацій та наукових розвідок, присвячених цьому мислителю, вражають уяву і більшість дослідників впевнені: ця глибока і далекоглядна філософія вочевидь матиме статус філософії XXI ст. Однак трапилось так, що філософія цього мислителя вклалася у певний стереотип, що деякою мірою викривило дійсні масштаби його мислення. На щастя, існують точки зору, які оцінюють філософію Л. Вітгенштейна як оригінальне спрямування, яке не $є$ ні логічним позитивізмом, ні аналітичною філософією у їі принципових сутностях. «3 іменем Вітгенштейна ослабли антиметафізичні емоції логічного позитивізму», - підкреслюе Г.-Г. Гадамер [2, с. 68]. Близьку точку зору відстоюе Г.Х. фон Врігт, учень і друг Вітгенштейна [4]. Він розглядає уявлення про нього як про філософа сциентистського спрямування як почасти не зовсім виправдане, більше того, підкреслюе, що Вітгенштейн не відчував симпатії до основних умонастроїв західної філософії з їі непохитною вірою в наукову раціональність.

Г. фон Врігт повідомляе, що роздуми Вітгенштейна зустрічали «опір нерозуміння» ще за його життя. Як засвідчують його сучасники, це засмучувало філософа, який попри укоріненість у класичній філософській традиціі, залишив нам таку філософську спадшину, яка важко вкладається у відомі філософські класифікації і не має аналогій з жодною $з$ персоналістичних філософських систем. «В його роздумах 
відчутні голоси Платона і Августина, Декарта і Канта, Шопенгауера, К'єркегора, Ніцше та ін. Але в пілому його філософія „заперечуе“ включенню її в межі прийнятних класифікацій. Ї̈і однозначно не впишеш в жодну з класичних традицій та і на філософській карті визначити її місце нелегко, - відзначає М.С. Козлова, - . . Лідери і учасники Віденського гуртка бачили у Вітгенштейні захисника наукового світорозуміння, яке самі вони оцінювали вище за все. У більшості, хто вивчав працю Вітгенштейна і знайомих з ідеями Віденського гуртка, також складалось враження: Рассел, Вітгенштейн, Карнап, Айер та ін. - це філософи одного типу, а назва логічний позитивізм відповідає загальному духу, розвиваючих ними позицій. Проте час показав, що Вітгенштейн не був їх однодумцем» [3, с.25-26]. Він не розглядав проблеми науки, його думка концентрувалась на самій філософії, причому розуміння $\dddot{1}$ суті і призначення мали принципово інший характер, що повертала вектор філософських міркувань у культурологічне і аксіологічне русло. Отже, Вітгенштейн не був довершеним раціоналістом, проте не був він і містиком, поглинутим прихованою ідеєю.

В дослідницькій літературі обговорюеться проблема розуміння філософії Вітгенштейна, її витоків і сенсу, однак майже зовсім не йдеться про ясні, з нашої точки зору, аналогії між нею і буддійським віровченням. Сьогодні доводиться констатувати, що характерний песимізм філософа щодо повноцінного розуміння сучасниками його новаторських висновків свідчить про надзвичайний інтелектуалізм його генія. У кінці свого життя Вітгенштейн прийшов до розуміння та спроби створення «нового образу» філософії, що має етичний зміст, співвідносний з етикою простоти, «досвіду мовчазного співбуття» як екзистенційного співпереживання; етичної дії спрямованої на добро і це дає підстави порівнювати таку етико-філософську модель з буддійським віровченням.

Етична лінія Вітгенштейна демонструє нехарактерну для загальної філософської думки точку зору на сенс мови і мовлення шляхом аналізу зв'язку слова (смислу) і контексту, ідеального і реального. Він підійшов до висновку, що існують базисні правила, які складають необхідну константу всіх випадків як контекстів використання мови і конституюють осмисленість. Але парадокс полягае у рефлексивності мови: ми можемо показати ці правила у мові, однак не можемо з'ясувати їх за її межами. Розуміння стану речей як певної мовної (етичної) гри або ж осмисленості відбувається за певними правилами і предбачае імпліцитні універсальні структури, конституюючі комунікативний досвід, який виявляється не чисто синтаксичним чи семантичним, а, перш за 
все, прагматичним. Зауважимо, що такий підхід достатньо далекий від позиції Вітгенштейна, однак логіка його роздумів виявилася співзвучною продуктивним ідеям сучасної доби, зокрема вона ясно проступає у концепції «життевого світу» Е. Гуссерля, у якій світ конституюеться та опосередковується мовою, таким чином, інструментальність мови складає важливий аспект «життєвого світу», одну 3 його смислотворчих констант. При цьому важливо відмітити, що життевий світ має нормативно-практичну природу. Знання того, що ми робимо, тлумачиться у якості фундаментальної феноменологічної установки ${ }^{1}$. Власне у феноменології так само йдеться про обгрунтовану філософом ідею «мовної гри» як певної функціональної єдності, що представляе собою форму життя. Таким чином, «філософія залишає все таким, як воно є»: функція інструментальності мови трансформується у базисний принцип розуміння. «У всьому треба шукати тільки дух. Але де ж він? Шукайте його в повсякденному житті»,- - гадуеться буддійська мудрість. Але ж для тих, хто звик до «строгої дисципліни» суб'єктоб'єктного логічного дуалізму ексцентризм такого висновку на перший погляд межуе з банальністю. Спробуємо пояснити цю думку інакше.

B час мовних новоутворень і нагромаджень та нескінченного комунікативного потоку, що розмиває ясність нашого мислення і спотворюе «розуміння» як форму світоглядної ідентичності, є особливо доречним звернутися до осмислення досвіду мінімізації комунікативної активності та оптимальної перспективи відповідності фактичного і смислового. 3 нашої точки зору, Вітгенштейн один $з$ перших у філософській думці намагався обгрунтувати цінність розуміння як такого кореляту людини і світу, мислення і буття, що у чистому вигляді є мовчанням. Згадаймо, що етика мовчання задовго до перших філософських систем була обгрунтована буддизмом, окреслюеться вона і у християнській традиції. Наприклад, практика такого досвіду розглядаеться в буддизмі як медитація - гармонійна єдність з реальністю чи то єдність суб'єкта і об'єкта, яка руйнується у процесі комунікативних та абстрактно-логічних надбудов. Така «перспективність» за своїм внутрішнім змістом $є$ близькою до філософії Вітгенштейна - «негативної

\footnotetext{
1 Нагадаємо, що феноменологія починае 3 повсякденних практичних завдань внрізняюонсь з-поміж інппх напрямків як «філософія повсякденності». У ній проблеми взаемозв'язку суб'єкта і об'екта переплетені 3 фактом чи ситуацією так як вони $е$, по відтворюеться у принпипі собітотожності іпдивіда (personal identity). Власне «повсякденність» не передбачае наявність інтелектуальних штучних утворень у вигляді інтелектуальних систем чи мовних нагромаджень, зведених до мінімуму. Осмисленість нашої дії визначаеться на основі недискурсивното за своею суттю принципу розуміння.
} 
метафізики» европейського зразка, у якій надзвичайно щільно переплітаються логіка, етика та епістемологія.

Знамениті слова буддійського мудреця: «Наслідування-це рабство» якнайкраще характеризують особистість Людвіга Вітгенштейна. Його філософський стиль, так само як і зміст міркувань, необхідно розглядати не стільки на фоні його історичної доби, як це зазвичай підкреслюеться дослідниками, стільки в деталях його психологічного портрету та біографії. Біографи філософа неодноразово підкреслюють його пристрасність до правди і щирості, чистих і простих форм сенсу життя, чесність перед собою та іншими, що послугувало причиною його розриву з високою академічною філософією, який вилився у самотню працю у якості сільського вчителя. Його філософські роздуми, позначені надзвичайною емоційною напругою, відчуттям духу втрати або ж виродження культури, що нагадує романтичну лінію філософії Ф. Ніцше. Ніцшеанський дух трагічної обраності, долання «стадного» завжди імпонував Вітгенштейну, проте ніколи не перекреслював, а скоріше, підкреслював єдину цінність абсолютного добра, яке не вкладається у межі дискурсивних визначень. Його ніколи не залишало відчуття, що поняття філософії як раціональної науки не наближається до істини, сутність якої прихована за мовною формою. «Вітгенштейн все свое свідоме життя знаходився в пошуках „природнього стану мови“. В Трактаті йому здавалось, що ця мова прихована під спотворюючим її обриси покровами повсякденної мови, що вона існуе десь глибоко під поверхнею мови, якою ми користуємося,- пише Г. фон Врігт. - Але там він їі не знайшов. Він просто не там пукав. Цю мову не можна знайти, пірнаючи під поверхню. Щоб знайти ї̈, треба вглядатись у цю саму поверхню. Тут повинна бути знайдена мова, яку він шукав» $[4$, с. 41$]$. Відмітимо, що таке бачення не вступае у суперечність з релігійно-філософською версіею буддизму i парадокс якраз і полягає у тому, що поворот до східної парадигми світорозуміння, загубленої під товщею тисячоліть, був здійснений західним аналітиком. «Мовчання золото»,- говорили мудреці; «вчення, незалежне від слів і букв», - пояснювали суть свого вчення буддійські патріархи. Етика мовчання, суб'єкт-об'єктної єдності як перебування у реальності співзвучна ідеям німецьких містиків - М. Екхарта, Я. Беме, співзвучна вона і етико-філософським засадам буддійського віровчення, яке відмовляється від антитезисного підходу визначення реальності. Спроби Вітгенштейна здійснитити «прорив» до самої суті філософії та істинного знання протягом багаторічної ретельної праці з текстовим матеріалом дозволили отримати серйозні результати, які 
важливо оцінити і зрозуміти як такі, що прокладають шлях до оригінальної етично-висвітленої онтології, що актуалізуе досвід логічної і граматичної простоти, доречного та вивіреного користування словом, досвід збереження, на відміну від досвіду перетворення. Отже, проблеми вирішуються не шляхом нарощення нової інформації, а шляхом впорядкування того, що нам вже відомо. Таким чином, вимальовується провідна функція філософії- функція впорядкування та збереження. Спроби надати філософії наукового статусу видаються філософу абсурдними, так само як і сама ідея універсальної мови науки та філософії як теоретичної доктрини. Увага філософа до природної мови продиктована її феноменологічними вимірами, що мають статус онтологічної і епістемологічної пріоритетності. Порівняемо: «Дзен і поняття - речі несумісні. Дзен не має справи з мовою. Та мова, яку ми використовуємо в даний момент, це просто мова, а не абстрактні поняття», - відзначае Д.Т. Судзукі [1, с. 391]. Як відомо, Вітгенштейн намагається підійти до обгрунтування категорії «чистої мови», чи мови, яка описуе світ у аб́солютно чистих неспотворених формах, що зрозуміло призвело до імперативу мовчання. «Але в кінці кінців він з'ясував, що форма і зміст „чистої“ мови невисловлювані. Мова, яку він шукав, за вдалим висловом Макса Блека, мова „ніколи-ніколи“. Вона настільки ж віддалена від мови, якою ми говоримо, як „Ніде“, земля чистого і простого життя, віддалена від зіпсованих суспільств, в яких ми змушені жити. Грунтуючись на тому, яким чином завбачається, що чиста мова Трактата повинна відповідати реальності, можна також сказати, що світ, який ця мова описуе, - це „світ-ніколи-ніколи“, проголошений ідеал, який ніде неможливо знайти. . . Як не існуе „чистої мови“" не існуе і „чистоі" реальності, яку б відображувала ця мова» [4, с. 41]. Таким чином, світ, описаний цією мовою-світ чистої реальності, наче не більше ніж метафора. Це дало підстави для скепсису та звинувачень у тому, що головний задум філософа-представити до розгляду модель ідеальної мови або ж знання - завершився поразкою. Але мало хто з дослідників був готовий звернути увагу на нашу «зачарованість» мовою, в той час як ясність наочного-абсолютна. 3 другого боку, ідеальна мова, яку намагається відтворити філософ, є важливий трансцендентальний принцип, відкритий для прояснень. По-перше, це принцип розуміння, мислимий як онтологічно-первинний стан речей - поверхня води, якої не торкається суб'єктивний інтелектуальний примус. Інтелектуальні прориви, логічні збурення, мовні утворення є грою нашого ратіо, і після гри все знову стає на свої місця, але при цьому витрачається щось надто цінне для гравців. Філософія 
як «лінгвістична хвороба» інтелекту не дає нам нічого нового. Якщо б розум міг впорядкувати світ раз і назавжди, то достатньо було б раз і назавжди даної однієї філософської системи, одначе історія думки показуе, що кожна нова геніальна надбудова врешті буде зруйнованою новим генієм, отже невтішний розум за своєю суттю вимагає такого роду діяльності. По-друге, ідея ідеальної мови співзвучна низці продуктивних філософсько-лінгвістичних ідей, окреслених феноменологією, герменевтикою, філософією постмодерну та концепціями онтологічної відносності природніх мов. По-трете, ідеальне не може бути дискурсивно фіксованим, тобто спиратися на фіксовану форму чи поняття: суб'єктивне мислення ідеї спотворюе її ідеальність як безумовну форму буття, що співпадае з безумовною формою мислення. Новаторська ідея «природного стану мови», очищеної від суб'єктивно-термінологічних нашарувань, відтворюеться у споглядальній практиці мовчазного розуміння знакової і смислової єдності речей і нагадуе нам категорію «чистого досвіду» аб̆о ж кожного конкретного особистого досвіду, що лежить в основі всіх переживань, притаманну філософії дзен ${ }^{2}$.

Подібні ідеї є вихідними у вченні дзен-буддизму, у якому істина незалежна від слів та букв, і це вже вказує на духовну сутність людини. I для філософа, і для буддійської філософії, розуміння є самоочевидним, воно не потребуе активізації чи нагнітання думки. Мова і розуміння грунтуються на етичній дії безвідносно до прагматично-раціональних міркувань і когнітивних проектів. Як правило, казуальність людського мислення схоплюе прагматичні перспективи. Однак це перекреслюе смисл і умову людської свободи. Свобода, як суто людська константа, потребує виходу за межі прагматизму, скерованості дії абсолютними началами, безвідносно до прагматичних мотивів.

Отже, вимальовуеться така світоглядна парадигма, яка наполягає на безпосередньому сприйнятті реальності, перебуванні у площині су-

\footnotetext{
${ }^{2}$ Зауважимо, по існують інші точки зору, фіксовані на небажанні Віттенштейна виходити за. межі вирішення конкретних терапевтичних задач, пов'язаних 3 «мовними іграми», оскільки сам автор концепңії «мовних ігор» вважав, пю зміг пояснити ситуапію смислової причетності як «сімейної схожості» різнорідних мовних ігор, не звертаючись до «мовної гри» більш високого порядку. Як вже зазначалося вище, він майже не торкаеться обтрунтування ідеї універсальної мовної грп, яка закладае межі розуміння для всіх мов, на відміну від ідеї вейдейтичної» мови Е.Гуссерля чи, наприклад, метатеорії мовних ігор П. Уїнча або теорії універсальної граматики Н. Хомського. Але ж, здаеться, загальновідомо, що внутрішній конфлікт філософа визрівав на тлі інтуітивного розумінғя випого порядку речей і стилю мислення, керованого професійною установкою логіка, що спрпчпнпло тяжіння філософа до «згортання» метафізики.
} 
б'єкт-об'ектної едності, редукції інтелектуально-логічної надбудови як помилкового уявлення про реальність. У будь-якому разі, узагальнення, що притаманні як філософському, так і науковому міркуванню, не $е$ «чистим досвідом», взятим у своїй конкретності, i ми ніколи не зможемо сягнути екзистенційних глибин, якщо будемо обмежуватися самим фактом формулювання понять екзистенціального змісту. Категорійний аналіз реальності, застосований філософією і наукою вимагае мовної інструментальності, яку ми мислимо картою реальності, але саме ця «зачарованість мовою, їі умовними поняттями та логічними конструкціями» пролягає між людиною і сущим і віддаляе нас від «чистого досвіду», який і є сама реальність. Дзен проявляе відразу до всього, що стоїть між нами і фактом. У факті немае боротьби між скінченним і нескінченним, між тілом і духом. Ці неіснуючі протистояння - плід розумової активності. «Щоб показати на місяць потрібний палець, але горе тому, хто приймае палець за місяць»,улюблена притча дзен. Перед нами факт і треба, щоб він не вислизнув від нас $[1$, с. 676$]$. Під особистим досвідом розуміється безпосередня едність $з$ фактом, а не опосередковане його сприйняття, що, на жаль, знову повертае до низки малоз'ясованих епістемологічних проблем: як визначити шукану єдність і вирізняти ї̈ з суб'єктивних варіантів опосередкованого сприйняття? Наприклад, Платон намагаеться прояснити такий стан речей наступними аргументами: істинне знання не отримуеться ні через відчуття, ні через емпіричний розсудок і вимагає чистого мислення. У свою чергу, за Кантом розум $\epsilon$ умовою можливості всих синтезів розсудку. I якщо розсудок заповнюеться чуттевим матеріалом, то розум спирається на ідеальний, надчуттевий або ж ноуменальний зміст, що знаходиться «по той бік» людського пізнання. I кожного разу, коли розум намагається проникнути в цей «порожній простір» і знову вибудовуе геніальну систему, він наштовхується на власні межі. Міркуючи про Платона, Кант приводить приклад про голуба, який вирішив покинути повітряний простір, забувши, що тільки в ньому і може літати. Отже, істина не може бути дана, а може бути тільки задана як здатність до безумовного. Така здатність $€$ внутрішньою потребою людини бути причетною до сфер, де теорія, логіка, мова втрачають свою цінність. Це сфера свободи. У людській волі, яка намагається реалізувати етичну мету, немає опори, у реальності ми не можемо знайти джерело нашої свободи, тому етика не може бути висловлена, етика трансцендентальна, як відзначають I. Кант і, пізніше, Л. Вітгеншейн. Така точка зору, що заперечуе «розсудковий інструменталізм», «різновидами» якого є логіка, мова, 
що прагнуть «вкласти» активність духу у певні форми, сприймається як нонсес. Однак ми повинні користуватись мовою, а не мова нами, говорили буддійські мудреці. «Захоплення» розуму мовою і логікою, відмова від безпосередньої данності речей нагадуе опору, без якої вона втрачає власні грандіозність і навіть суть. I парадокс ситуації виявляється в тому, що коли ми позбавляємо себе всякої опори, то відчуваємо, що віднайшли більше ніж загубили - ясність чистого досвіду та онтологічну неспотвореність етичного. На думку Л. Вітгенштейна, який гостро усвідомлював, що не є продовжувачем традиційної філософії на зразок філософії Лейбніца чи Гегеля, філософські проблеми не вирішуються логічним чи граматичним аналізом мови, а, навпаки, виникають внаслідок хибного розуміння справжньої суті мови, їі функцій та внутрішньої логіки. Людські істоти глибоко зав'язли у логічно-науковій та граматичній плутанині. I вирватися 3 неї вдасться лише тим, хто переміг стадний мовний інстинкт і зрозумів онтологічний сенс мови не як засобу самовираження, а як передумову розуміння, сутність якого ніяк не позначена на карті буття. Отже, «мовчання» е абсолютний досвід (реальність), що редукуе потребу логічних міркувань. Мова, якщо вона мислиться в логічних чи символічних константах, не може бути пізнаваною у своїх істинних вимірах як «попередне буття охопленості всього сущого» (Г.-Г. Гадамер).

Отже, спадщина Вітгенштейна так і залишається суперечливою i нез'ясованою у своїй суті. Назвавши його позитивістом, більшість знайшла для себе проблематичним побачити його зовсім у іншому світлі намаганні пояснити необхідність неіснуючого, втілити у дійсність нездійсненне та відмовитись від двоїстого «еgо». «Цей професор філософії не міг дозволити собі органічно увійти в академічний істеблішмент одного 3 найвидатніших університетів світу. . . Цей Вітгенштейн, який корінним чином змінив свій спосіб життя, був близький до нової філософії, яка для більшості його прихильників ставала все менш близькою за своїм духом» [4, с. 38]. Як правило, вважається, що існує суттєва відмінність між раннім та пізнім Вітгенштейном, 3 притаманним останньому глибоким скепсисом щодо впливу наукового раціоналізму на наше мислення і життя. Його думка здійснила те, що можна визначити як «філософський оберт»: від поверхні логічно-конкретного до глибин трансцендентного і від них знову до поверхні, але вже в новій, екзистенційно-фактичній ясності повсякденного, заданого дійсним, але ж невисловлюваним. Але ж і буддизм багато століть тому намагався висвітлити думку про те, що послідовне логічне міркування, мовні обриси наявних подій не $\epsilon$ самодостатнім чи природнім станом люд- 
ського духу, а трансцендентальним вираженням внутрішнього стану, недосяжного інтелектуальному аналізу: «У виключенні чи обмеженні не може бути свободи. Дзену це прекрасно відомо. Відповідаючи на поклик душі, дзен веде нас до абсолютної істини, що не знае антитезн» [1, c. $383-384]$.

Отже, головне завдання людини - зберегти ясність розуму, чесність душі та велич духу, не впадаючи в оману філософських взірців та «мовних» чар. Тільки вища істина не е продуктом відносного знання і має витоки у сутності особистісного духу. Це і $є$ головною темою «невисловлюваного», досвіду «мовчання» і відповідного йому стилю життя, мотивацій, вчинків, та вищих цінностей, яким присвятив своє неяскраве життя один із найбільш яскравих мислителів XX століття.

\section{1 Бібліографія}

[1] Буддизм. Четыре благородных истины.-М.: $3 А О$ Изд-во ЭКСМО-пресс; Харьков: Изд-во Фолио, 2000.

[2] Гадамер Г.-Г. Істина і метод. - К.: Юніверс, 2000.

[3] Козлова М.С. Витгенштейн: новый образ философии // Вопросы философии. - 2001. - ㄹ 7.- С. 25-33.

[4] бoи Bpuzm Г.-X. Витгенштейн и двадцатый век //Вопросы философин. -2001 . - a 7 . - С. $33-47$. 